\title{
A Short Review on Cockle Shells as Biomaterials in the Context of Bone Scaffold Fabrication
}

(Kajian Ringkas Cengkerang Kerang sebagai Bio-Bahan dalam Konteks Fabrikasi Perancah Tulang)

PenNy GeOrge, ZARIYANTEy Abdul HAMId, Md ZuKi Abu BAKAR@ZAKARIA, ENOCH KUMAR PERIMAL \& HEMABARATHY BHARATHAM*

\begin{abstract}
Cockle shells contribute to a large amount of waste product in South East Asia due to the extensive culturing of the mollusc for consumption. These nacreous materials in the recent years have been gaining wider popularity due to its potential use as biomaterials. As shown in various studies, cockle shell powder consists of 95-98\% aragonite form of calcium carbonate $\left(\mathrm{CaCO}_{3}\right)$. The calcium carbonate obtained from cockle shells are easily converted into nanoparticles, which have shown encouraging results in bone tissue grafting. With the recent advancement in bone tissue engineering and development of a newer generation of biomaterial based bone scaffolds, the cockle shell powder has promising applications in the near future to be used in the formulation of bone grafting materials. In this review, the use of biomaterials in bone tissue grafting and nacreous materials as potential biomaterials with a focus on the cockle shell and its recent advancement as the main component in the formulation of a nanobiocomposite bone scaffold is discussed.
\end{abstract}

Keywords: Biomaterial; bone tissue grafting; cockle shell

\section{ABSTRAK}

Kulit kerang menyumbang kepada sejumlah besar sisa di Asia Tenggara disebabkan oleh industri ternakan kerang yang berleluasa. Kebelakangan ini penggunaan bahan-bahan nakreus sebagai salah satu jenis biobahan yang berpotensi tinggi semakin mendapat perhatian. Hasil kajian sebelum ini menunjukkan bahawa kulit kerang mengandungi $96-$ 98\% kalsium karbonat ( $\mathrm{CaCO}_{3}$ ) dalam bentuk polimorf aragonite. Fasa aragonite ini didapati mudah ditukar kepada fasa nano yang menunjukkan hasil yang memberangsangkan dalam kejuruteraan tisu tulang. Dengan kemajuan dalam bidang kejuruteraan tisu tulang serta pembangunan perancah tulang generasi baru berasaskan biobahan, serbuk kulit kerang didapati sesuai digunakan untuk pelbagai aplikasi termasuk formulasi bahan cantuman tulang. Penggunaan biobahan untuk aplikasi kejuruteraan tisu tulang dan potensi biobahan berasaskan bahan-bahan nakreus terutamanya kulit kerang serta penggunaannya sebagai salah satu komponen utama dalam pembangunan perancah tulang nanobiokomposit dibincangkan dalam ulasan ini.

Kata kunci: Biobahan; kulit kerang; penyambungan tisu tulang

\section{INTRODUCTION}

In recent years, material science has advanced towards utilizing biomaterials in designing tissue engineered materials to aid in the restoration of damaged tissues. Numerous studies had been undertaken in regards to the formulation of bone grafts, paste and scaffolds in the field of bone tissue engineering. These materials must be biocompatible and biodegradable to provide an optimal function for tissue regeneration. It is also an added advantage for such biomaterials to be lightweight. A biomimetic fabrication strategy becomes a great point to look at, where the structure is highly controlled and optimized at several scales. The mechanical properties of the biomaterial are crucial in bone tissue engineering and may be satisfied by structurally clever designs inspired by fabrication strategies found in nature (Xie et al. 2010).

\section{BIOMATERIALS FOR BONE REPAIR AND GRAFTING}

Biomaterials refer to any material, either natural or synthetic that could be used to interact within a biological system and were first developed in the 1960's and 1970's. The third generation of biomaterials was developed to be highly bioactive with excellent resorbable properties. These materials were also designed to possess potentials for stimulating a specific cellular response at the molecular level (Hench \& Polak 2002).

In the context of bone tissue engineering, a biomaterial often refers to a delivery system that is designed through an adequately shaped three dimensional (3D) scaffold for bone repair which could ideally combine osteoconductive and osteoinductive properties (Luginbuehl et al. 2004). Several criteria that should be fulfilled by the biomaterial based scaffold in order to enhance bone fracture healing include 
the ability to promote the recruitment and attachment of cells as well as to facilitate cell migration and angiogenesis through its allocated void spaces. A 3D based scaffold could also possibly be linked with a bioactive growth factor that is released in a timely dose controlled manner (Luginbuehl et al.2004). These types of biomaterials can be used to intimately associate with various host constituents for a prolonged period to provide the necessary chemical and physical cues which could drive the tissue repair and regeneration process in a faster manner. Additionally, the biomaterial based scaffold should be highly biocompatible with adequate biodegradability, low toxicity as well as a cost effective alternative (Li \& Wozney 2001).

In order to obtain the optimal regeneration, a biomaterial used in bone tissue engineering should possess a degradation rate which is almost similar to the regeneration rate of the bone. This criterion implies as an essential aspect of bone tissue engineering as the biomaterials transplanted should persist long enough to allow bone formation inside and until the total replacement of the bone is achieved (Scheller et al. 2009). Though biomaterial based bone tissue engineering is still far from ideal bone substitution due to the lack of osteogenic and osteoinductive properties, they still have significant benefits in terms of availability, reduced risk of donor rejection and complications. The possibilities of integration of the desired growth factors and other modulating factors that could enhance healing in a faster manner could also easily be attempted with these materials. The use of biomaterials is further intensified in settings where the lesions are larger than $6 \mathrm{~cm}$ to $9 \mathrm{~cm}$ rendering the use of an autograft insufficient (Avila et al. 2009). In such cases, the use of biomaterials becomes an essential part of bone tissue healing in order to at the least provide the fundamental need of bone tissue regeneration such as a support matrix, porous voids for adequate cell migration and angiogenesis as well as mechanical integrity. These biomaterials could further be enhanced through the incorporation of growth factors in order to possess osteoinductive properties.

The search for an adequate biomaterial based bone scaffolds for bone tissue healing is an ongoing process which opens up an exciting and sophisticated field of study which requires innovation in order to achieve the ideal bone tissue replacement materials in the near future. Some of the most commonly used biomaterials in the bone tissue engineering paradigm include materials such as glass ionomers, calcium phosphate cement, calcium sulphate, aluminium oxide, bovine xenografts, bioactive glasses, synthetic hydroxyapatite, coralline hydroxyapatite, calcium carbonate and composite polymers (Perez-Sanchez et al. 2010).

The uses of calcium carbonate as a potential biomaterial in bone tissue regeneration are only gaining popularity in the recent years. With the present focus of interest in nanotechnology, calcium carbonate is easily converted into nanoparticles that have been observed to be biocompatible for use in medicine, pharmaceutical industries, and drug delivery systems (Fukui \& Fujimoto
2012). Calcium carbonate consists of three polymorphs that include calcite, aragonite and vaterite. Calcite is thermodynamically stable under ambient condition while aragonite is a high pressure polymorph that is less stable than calcite. Vaterite is the least stable compared to calcite and aragonite and has the ability to transform into one of the other two polymorphs (Guowei et al. 2009). An abundant cheap source of calcium carbonate can be obtained from nacreous materials. The cockle shell is one such source that consists of calcium carbonate as the primary component with early research on it showing very promising results as a biomaterial for tissue engineering (Hemabarathy et al. 2014; Mohamed et al. 2012). As shown in our previous studies, the cockle shell powder consists of an aragonite form of calcium carbonate which is, interestingly, more biocompatible with better potentials to be naturally converted to bone.

\section{SHELLS AND NACREOUS MATERIALS}

Mollusca is the largest phylum of invertebrate animals with a vast amount of species. The members of the phylum are called molluscs. A majority of the molluscs produce external calcified shells (Williams et al. 2016). The phylum Mollusca consist of eight classes under two main divisions, the Conchifera and the Aculifera. The Conchiferas are species with shells including bivalves, cephalopods, gastropods, scaphopods and monoplacophorans, while Aculiferas lacks shells and consists of the polyplacophorans, caudofoveafes and solenogastres (McDougall et al. 2018; Vinther et al. 2012). Since Aculiferan molluscs have no shells, a considerable number of studies on molluscan biomineralization are focused on the shells of Conchiferan molluscs.

Molluscan shells are produced by the outer fold of the mantle (Budd et al. 2014). Shells are defined as a multilayered structure with composition incorporating calcium carbonate $\left(\mathrm{CaCO}_{3}\right)$ crystals, proteinaceous material and pigments which vary from taxon to taxon (Felipe 2015; McDougall et al. 2018). The thin outermost proteinaceous layer of the shell is known as periostracum, a noncalcified layer which is composed of organic components (Felipe 2015; McDougall et al. 2018; Szabo 2008). It acts as the initial site for shell deposition and has a protective function against shell corrosion in some species (Taylor et al. 1969; Williams et al. 2016). The underlying calcareous layer of the shell is composed of either aragonite and/or calcite forms of $\mathrm{CaCO}_{3}$ and an enclosed $\mathrm{CaCO}_{3}$ mesocrystals (Felipe 2015; McDougall et al. 2018; Szabo 2008) that is always found in several molluscan classes including gastropods, cephalopods, bivalves and monoplacophorans (Marin et al. 2012; McDougall et al. 2018). Whether aragonite or calcite, $\mathrm{CaCO}_{3}$ crystals are laid down in a variety of defined microstructure types (Szabo 2008). The multilayered of the shell may contribute to the different microstructure that will influence the physical characteristics of the shell including the strength and appearance (Williams et al. 2016), which causes 
each gastropod, bivalve, and cephalopod nacre to display different crystallographic axes (McDougall et al. 2018). The mollusc shell has an ideal characteristic to become a bioceramic material candidate, with its sophisticated porous structure and adequate fracture strength and toughness (Ige et al. 2012; Yin et al. 2016).

There are numerous shells in nature and according to prelude result, certain types of shells have great potential as biomedical materials. One of the best examples is the nacre or commonly known as 'mother-of-pearl' which forms the iridescent inner surface of certain molluscan shells (Ige et al. 2012; Kakisawa et al. 2011; McDougall et al. 2018). It comprises of $0.5 \mathrm{~m}$ thick and $10 \mathrm{~m}$ wide stacked plates arranged in a 'brick-and-mortar' microstructure with an organic matrix interlayer. The nacreous structure is known to be the strongest among all other shell structures ( $\mathrm{Li}$ et al. 2012; Yin et al. 2016). The nature of the nacre's is to absorb fracture and prevent the catastrophic damage towards the shells (Meyers et al. 2008). The combination of hard minerals and soft biopolymers in the structure of nacre helps in the better mechanical performance of the material (Kakisawa et al. 2011; Meyers et al. 2008) and a potential candidate for bone tissue engineering.

\section{COCKLES}

Cockle is a bivalve marine mollusc from the species of Anadara granosa which is mostly used as a source of protein rich food. Cockles or better known as 'blood cockles' belongs to the family Archidae, a small, consumable sea clams which are available commonly in many Southeast Asian countries. The molluscs are cultivated predominantly from its aborigin, which is the intertidal mudflat and is typically found around mangrove estuary and muddy areas. It is always important to consider the spawning and growth habitat before the harvest and culture of the cockles. Countries such as Malaysia, Indonesia and Thailand are known for their extensive cockle industry (Boey et al. 2011; Jaji et al. 2017; Yurimoto 2013) with an annual blood cockle harvest exceeding 520, 515 tonnes in Malaysia alone in the year 2014 (DOFM 2014). The shells of the cockles are literally of no use and contribute to a significant amount of waste products. This waste product generated after the mussels are consumed is slowly being put to proper use by finding its applications in a vast range of industries. The rich calcium carbonate based shells of the cockle offer an attractive alternate material which is cheap, readily available and abundantly present for the use in the fabrication of calcium based bone grafting materials. Many studies have discovered that cockle shells consists of about $95-98 \%$ of $\mathrm{CaCO}_{3}$ with a remaining composition of magnesium $(\mathrm{Mg})$, sodium $(\mathrm{Na})$, phosphorus $(\mathrm{P})$, potassium $(\mathrm{K})$ and other minerals (ferum $(\mathrm{Fe})$, copper $(\mathrm{Cu})$, nickel $(\mathrm{Ni})$, boron $(\mathrm{B})$, zinc $(\mathrm{Zn})$, and silicon (S)) (Asmi et al. 2017; Saffanah et al. 2017; Sari et al. 2016). The naturally synthesized $\mathrm{CaCO}_{3}$ in cockle shells predominantly contains the aragonite polymorphs of $\mathrm{CaCO}_{3}$ (Hoque et al. 2013; Islam et al. 2013). The naturally occurring aragonite from the cockle shells are found to be highly purified and was proved to be safe for human consumption or medical use due to the below detectable levels of heavy metals (Ghafar et al.2017; Hemabarathy et al. 2014). The denser nature of aragonite also enhances its capability for drug delivery development and bone grafting making it an attractive biomaterial for tissue engineering applications (Ahmad et al. 2017; Saffanah et al. 2017; Saidykhan et al. 2016).

\section{COCKLE SHELLS AS BIOMATERIAL FOR BONE SCAFFOLD FABRICATIONS BONE SCAFFOLDS}

Studies on cockle shell powder have shown a better use of it as a potential biomaterial for fabrication of bone scaffold. A scaffold is an extracellular matrix which is manipulated and manufactured to form a three dimensional (3D) structure capable of performing significant functions. In the field of tissue engineering, it is always favored that the implanted scaffold degrades as soon as the tissue has developed and functions of the lost bone tissues are restored (Shafiu et al. 2014). To ensure these criteria's are met, current developments in bone substitute materials are highly focused in using biocompatible materials capable of producing scaffolds that have sufficient physical and mechanical characteristics without exerting any form of cytotoxic effects at the cellular level. With the recent interest in nanotechnology, it is proven that the use of materials in nano scale contributes to a stronger bonding and mechanical stability (Yin et al. 2014). Scaffolds based on nanomaterials are also shown to possess better cellular interaction and an accelerated tissue response that shortens healing time.

The cockle shell powder (Figure 1(a)) has an added advantage of undergoing a simple biochemical reaction that enables the powder to be easily converted into a nanophase material (Islam et al. 2012). This advantage of the cockle shell powder has been manipulated for the past years in the fabrication of novel nanocomposite bone scaffolds as reported in studies by Hemabarathy et al. (2014), Islam et al. (2012) and Saffanah et al. (2017). In (2012), Islam et al. successfully established the very first basic preparation methods in synthesizing nanoparticles from cockle shells using simple novel biochemical methods with dodecyl dimethyl betaine or commonly known as BS-12. In a subsequent study by Shafiu et al. (2013), preparation of nano cockle shell powered using a high pressure homogenizer technique in the presence of a surfactant (Tween 80) was attempted. Though the procedure did produce promising results for nanoparticle production from cockle shells, the method, however, did not gain much attention as various limitations including expensive complex equipment were required and were not as cost effective to be carried out for large scale productions. Over the past years, the methods introduced by Islam et al. (2012) has been used in the preparation of nano cockle shell powder which is found to be more cost effective and consistent (Ghafar et al. 2017). 

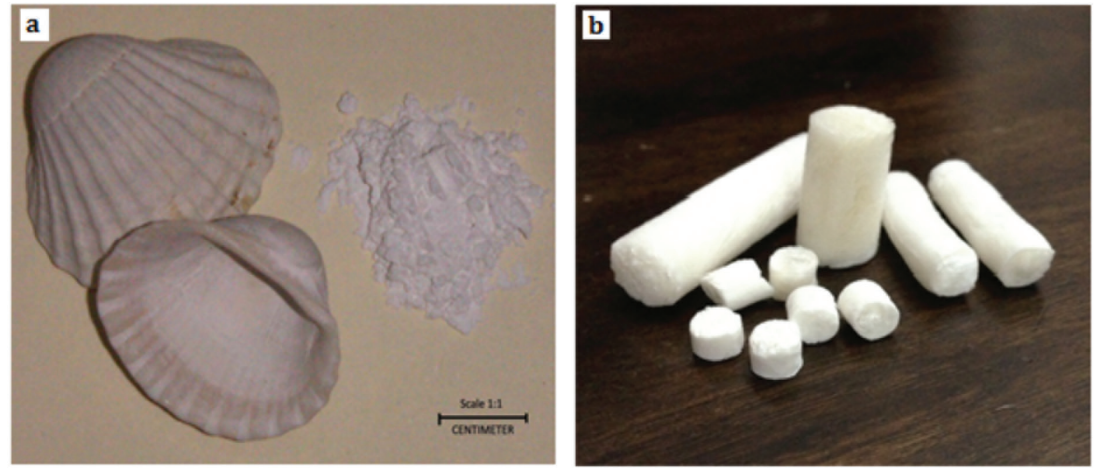

FIGURE 1. (a) Gross and powdered appearance of cockle shells and (b) nanobiocomposite bone scaffolds fabricated from nano cockle shell powder and alginate

\section{FORMULATING AN IDEAL COCKLE SHELL POWDER} BASED BONE SCAFFOLD

In recent years, many formulations of bone scaffold using cockle shell powder has been successfully fabricated and studied. The key to fabrication of the scaffold involves the production of a biocomposite material that has an added advantage in increasing the physical, mechanical properties and biostability of the end product. The use of additional polymeric materials in the process of fabrication of the scaffold plays a crucial role to determine the successful outcome of the scaffold. In a recent study, Saffanah et al. (2017) successfully fabricated a scaffold using a combination of gelatin, dextran and dextrin with nano cockle shell powder to develop a nanobiocomposite scaffold. A more widely studied nanobiocomposite scaffold consisting of the nano cockle shell powder was previously fabricated using alginate as representatives of the polymeric state as shown in Figure 1(b) (Hemabarathy et al. 2014). The fabrication of this scaffold involved the mixing of nano cockle shell powder and alginate under constant stirring on a homogenize stirrer machine to form a homogenized smooth slurry. The mixture was prepared and characterized in many different ratios with alginate: nano cockle shell powder in a ratio of 40:60 (w/v) being reported to have the most ideal characteristics of a bone grafting material.
Further studies conducted on this fabricated scaffold have revealed ideal bone grafting characteristics such as porous morphological structure and excellent cell response towards adherence of osteoblast towards the scaffold material. As shown in Figure 2(a), the scaffold fabricated was also reported to have an excellent porosity of above $70 \%$ (Hemabarathy et al. 2014). Porosity is one of a few primary characteristics in the designation of a scaffold, which influence the mechanical properties and biological activities of a scaffold as supported by Zhang et al. (2014). An optimum range for the interconnected porosity is between 60-90\% and according to Haripal et al. (2012), Peter et al. (2010) and Sharma et al. (2016), high porosity of a scaffold aids in cell seeding as well as facilitating diffusion of nutrients and oxygen besides providing enough space for cell adhesion and regeneration of extracellular matrix. Vascularization and cell migration were enhanced by an increase in porosity which leads to a faster healing process (Hasan et al. 2018; Hemabarathy et al. 2017). Studies have shown that scaffolds fabricated using cockle shell powder is cytocompatible as it enhances cell proliferation. This might be due to the calcium contained in the cockle shell that promotes the cells attachment and proliferation rate. Calcium ions are known biomolecules that determines the early cell behavior which are also known as an osteogenic stimulant. Presences of calcium
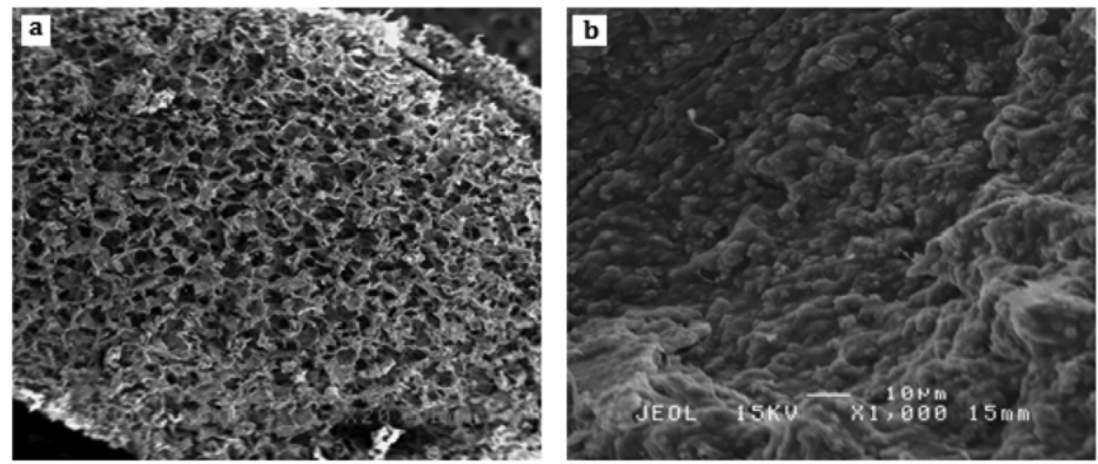

FIGURE 2. (a) SEM micrograph showing porous morphology and (b) deposition of nano cockle shell powder on the polymer matrix of the nanobiocomposite bone scaffold $(a: \times 20 ; b: \times 1000)$ 

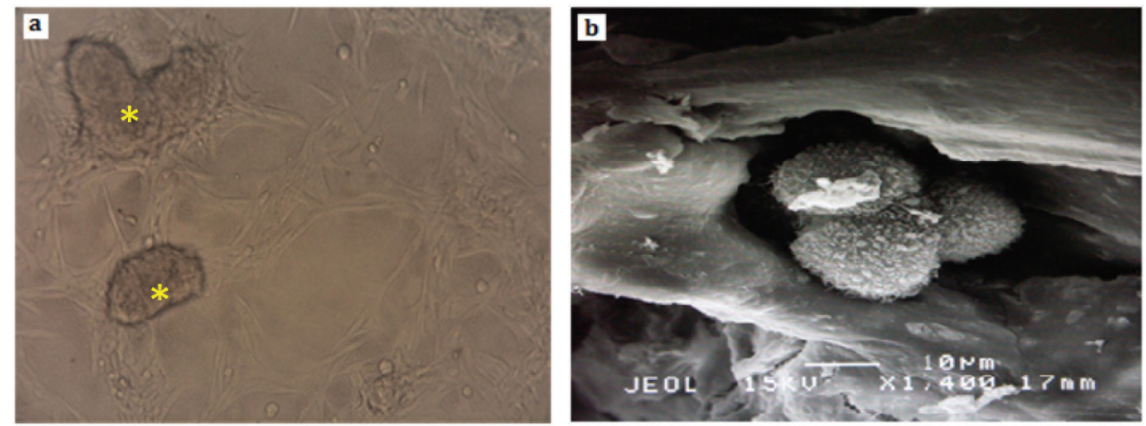

FIGURE 3. (a) Adherence of osteoblast towards the fragments of scaffold* and (b) SEM micrograph of cells attached to the surface of scaffold matrices

deposits from the cockle shell powder on the surface of the fabricated scaffold (Figure 2(b)) contribute to the topographical factor of the scaffolds that positively affects the cellular response (Ahmad et al. 2017; Hemabarathy et al. 2014; Peter et al. 2010; Sharma et al. 2016). Figure 3 shows the favorable adherence of osteoblast around fragments of the nanobiocomposite scaffold in a culture plate as well as on the underlying matrices of the scaffolds. In an in vivo experiments conducted on the alginatecockle shell powder nanobiocomposite scaffold through implantation of osteoblast seeded scaffold into the dorsum of experimental mice, showed no exerted tissue response and absence of inflammation indicating that the scaffold was highly biocompatible and supported the formation of bone tissues and angiogenesis (Hemabarathy et al. 2017).

In addition to an excellent tissue response, it is noticeable that, the aragonite polymorph of $\mathrm{CaCO}_{3}$ comprises of a high compressive strength due to its meta stable property under all type of biological conditions. According to Saffanah et al. (2017), a combination of $50 \%$ cockle shell nanoparticle, $25 \%$ gelatin, $10 \%$ dextran and $15 \%$ dextrin for the formulation of bone scaffold has shown a better compressive strength of up to $20.3 \mathrm{MPa}$. While the combination of $60 \%$ nano cockle shell powder with $40 \%$ alginate was reported to have a compression strength of 3.4 MPa that was found to range between the spongy bone structure of 2 - $12 \mathrm{MPa}$ (Bose et al. 2012). Similarly, Muthusamy et al. (2012) reported that a higher value of compressive strength could be seen in concrete mixed with $20 \%$ cockle shell compared to plain concrete. This result might be due to the rough surface of the cockle shell which strengthens its bonding property with the concrete to increase the overall compression strength. The fracture toughness feature of the cockle shell are highly valuable for multiple applications that are not only limited for bone grafting.

\section{CONCLUSION}

Future researches on scaffold fabrication are considering the adequateness of suitable characteristics of a grafting material in regards to its porosity, mechanical strength, degradability and cytotoxicity for the regeneration of new bone tissue. The quest for biomaterials for tissue engineering is an ever expending field of study each aiming to fulfill these ideal characteristics of a bone grafting material, which could potentially find a place in the clinical settings. Focus on shells and nacreous materials such as the cockle shell provides a cheaper and endless alternative in the formulation of an ideal bone grafting material. Due credits are given to the aragonite calcium carbonate in the cockle shells that are capable of integrating into natural bones as they resolve when used as implant materials. The expanding studies on nanobiocomposite bone scaffold using cockle shell powder shows promising production of bone scaffolds that could fulfil the criteria of the ideal bone grafting material as previously mentioned. It could not be denied that these studies are still at its infancy and further evaluations and reporting has to be done before potential products with clinical commercialization is produced using the cockle shell powder.

\section{REFERENCES}

Ahmad, N.B., Hemabarathy, B., Hamid, Z.A. \& Zulkipli, N.Z. 2017. Cytotoxicity and oxidative stress evaluation of alginate/ cockle shell powder nanobiocomposite bone scaffold on osteoblast. Jurnal Sains Kesihatan Malaysia 15: 97-103.

Asmi, D. \& Zulfia, A. 2017. Blood cockle shells waste as renewable source for the production of biogenic $\mathrm{CaCO}$ and its characterisation. IOP Conference Series: Earth and Environmental Science 94: 012049.

Avila, G., Misch, K., Galindo-Moreno, P. \& Wang, H.L. 2009 Implant surface treatment using biomimetic agents. Implant Dentistry 18(1): 17-26.

Boey, P.L., Maniam, G.P., Hamid, S.A. \& Ali, D.M.H. 2011. Utilization of waste cockle shell (Anadara granosa) in biodiesel production from palm olein: Optimization using response surface methodology. Fuel 90: 2353-2358.

Bose, S., Roy, M. \& Bandyopadhyay, A. 2012. Recent advances in bone tissue engineering scaffolds. Trends in Biotechnology 30(10): 546-554.

Budd, A., Mcdougall, C., Green, K. \& Degnan, B.M. 2014. Control of shell pigmentation by secretory tubules in the abalone mantle. Frontiers in Zoology 11: 62.

Department of Fisheries Malaysia (DOFM). 2014. Principal Statistics of Marine Fish Landing, Aquaculture and Inland Fishery Production and Value, 1988 - 2014, Malaysia. Department of Fisheries Malaysia, Putrajaya. 
Felipe, E.A.M. 2015. Investigation of gene family evolution and the molecular basis of shell formation in molluscs. The University of Queensland, Australia (Unpublished).

Fukui, Y. \& Fujimoto, K. 2012. Bioinspired nanoreactor based on miniemulsion system to create organic-inorganic hybrid nanoparticle and nanofilm. Journal of Material Chemistry 22(8): 3493-3499.

Ghafar, M.S.L., Hussein, M.Z., Rukayadi, Y.\& Zakaria, M.Z.A.B . 2017. Synthesis and characterization of cockle shell-based calcium carbonate aragonite polymorph nanoparticles with surface functionalization. Journal of Nanoparticle 2017: Article ID. 8196172.

Guowei, Y., Wang, L. \& Jianhua, H. 2009. The crystallization behavior of calcium carbonate in ethanol/water solution containing mixed nonionic/anionic surfactants. Powder Technology 192(1): 58-64.

Haripal, G.S. 2012. Preparation and characterization of PLA and PLGA scaffold and film. Thesis of Master Degree in Life Science, Department of Life Science. National Institute of Technology, Rourkela (Unpublished).

Hasan, A., Waibhaw, G., Saxena, V. \& Pandey, L.M. 2018. Nanobiocomposite scaffolds of chitosan, carboxymethyl cellulose and silver nanoparticle modified cellulose nanowhiskers for bone tissue engineering applications. International Journal of Biological Macromolecules 111: 923-934.

Hemabarathy, B., Hamid, Z.A., Musa, M.F., Ahmad, N. \& Perimal, E.K. 2017. Perbandingan antara perancah tulang nanobiokomposit alginat/kulit kerang dan alginat/kalsium karbonat terhadap pertumbuhan osteoblas. Jurnal Sains Kesihatan Malaysia 15(2): 1-7.

Hemabarathy, B., Md. Zuki, A.B.Z., Perimal, E.K., Yusof, L.Q. \& Hamid, M. 2014. Mineral and physiochemical evaluation of cockle shell (Anadara granosa) and other selected molluscan shell as potential biomaterials. Sains Malaysiana 43(7): 1023-1029.

Hench, L.L. \& Polak, J.M. 2002. Third-generation biomedical materials. Science 295(5557): 1014-1017.

Hoque, E., Shehryar, M. \& Islam, K.N. 2013. Material science $\&$ engineering processing and characterization of cockle shell calcium carbonate $\left(\mathrm{CaCO}_{3}\right)$ bioceramic for potential application in bone tissue engineering. Journal of Material Science and Engeneering 2: 2-6.

Ige, O.O., Umoru, L.E. \& Aribo, S. 2012. Natural products: A minefield of biomaterials. ISRN Materials Science 2012: $1-20$.

Islam, K.N., Md Zuki, A.B.Z., Md Eaqub, A., Hussein, M.Z., Noordin, M.M., Loqman, M.Y., Wahid, H., Hakim, M.A. \& Hamid, S.B.A. 2012. Facile synthesis of calcium carbonate nanoparticles from cockle shells. Journal of Nanomaterials 2012: 1-5.

Islam, N., Md Zuki, A.B.Z., Md Eaqub, A., Hussein, M.Z., Noordin, M.M., Loqman, M.Y., Miah, G., Wahid, H. \& Hashim, U. 2013. A novel method for the synthesis of calcium carbonate (aragonite) nanoparticles from cockle shells. Powder Technology 235: 70-75.

Jaji, A.Z., Md Zuki,A.B.Z., Mahmud, R., Yusof, M.L., Mohamad, M.N.H., Isa, T., Fu., W. \& Hammadi, N.I. 2017. Synthesis, characterization, and cytocompatibility of potential cockle shell aragonite nanocrystals for osteoporosis therapy and hormonal delivery. Nanotechnology, Science and Applications 10: 23-33.
Kakisawa, H. \& Sumitomo, T. 2011. The toughening mechanism of nacre and structural materials inspired by nacre. Science and Technology of Advanced Materials 12: 064710.

Li, H.Y., Ye, Q.T., Lu, Z., Yun, X.Z., Yi, H.S., Ying, Y. \& Xia, M.S. 2012. BioFiller from waste shellfish shell: Preparation, characterization, and its effect on the mechanical properties on polypropylene composites. Journal of Hazardous Materials 217-218: 256-262.

Li, R.H. \& Wozney, J.M. 2001. Delivering on the promise of bone morphogenetic proteins. Trends in Biotechnology 19(7): 255-265.

Luginbuehl, V., Meinel, L., Merkle, H.P. \& Gander, B. 2004. Localized delivery of growth factors for bone repair. European Journal of Pharmaceutics and Biopharmaceutics 58(2): 197-208.

Marin, F., Le Roy, N. \& Marie, B. 2012. The formation and mineralization of mollusk shell. Frontiers in Bioscience 4: 1099-1125.

McDougall,C. \& Bernard, M.D. 2018. The evolution of mollusc shells. Wiley Interdisciplinary Reviews: Developmental Biology 7(3): 1-13.

Meyers, M.A., Chen, P.Y., Lin, A.Y.M. \& Seki, Y. 2008. Biological materials: Structure and mechanical properties. Progress in Materials Science 53: 1-206.

Mohamed, M., Yusup, S.\& Maitra, S. 2012. Decomposition study of calcium carbonate in cockle shells. Journal of Engineering Science and Technology 7(1): 1-10.

Muthusamy, K., Sabri, N., Resources, E. \& Razak, L.T. 2012. Cockle shell: A potential partial coarse aggregate replacement in concrete. International Journal of Science, Environment and Technology 1: 260-267.

Peter, M., Binulal, N.S., Soumya, S., Nair, S.V., Furuike, T., Tamura, H. \& Jayakumar, R. 2010. Nanocomposite scaffolds of bioactive glass ceramic nanoparticles disseminated chitosan matrix for tissue engineering applications. Carbohydrate Polymers 79(2): 284-289.

Perez-Sanchez, M.J., Ramirez-Glindon, E., Lledo-Gil, M. \& Calvo-Guirado, J.L. 2010. Biomaterials for bone regeneration. Medicina Oral Patologia Oral y Cirugia Bucal 15: 517-522.

Saffanah, K.M., Md Zuki, A.B.Z., Intan, S.A.R., Loqman, M.Y., Alhaji, Z.J., Isa, T. \& Nahidah, I.H. 2017. Preparation and characterization of cockle shell aragonite nanocomposite porous 3D scaffolds for bone repair. Biochemistry and Biophysics Reports 10: 237-251.

Saidykhan, L., Bakar, M.Z.B.A., Rukayadi, Y., Kura, A.U. \& Latifah, S.Y. 2016. Development of nanoantibiotic delivery system using cockle shell-derived aragonite nanoparticles for treatment of osteomyelitis. International Journal of Nanomedicine 11: 661-673.

Sari, R.P., Hermanto, E., Divilia, D., Candra, I., Kuncoro, W. \& Liswanti, T. 2016. Effects of Anadara granosa shell combined with Sardinella longiceps oil on oesteoblast proliferation in bone defect healing process. Dental Journal (Majalah Kedoktoran Gigi) 49: 27-xxx.

Scheller, E.L., Krebsbach, P.H. \& Kohn, D.H. 2009. Tissue engineering: State of the art in oral rehabilitation. Journal of Oral Rehabilitation 36(5): 368-389.

Shafiu, K.A., Ismail, M., Ibrahim, T.A.T. \& Zakaria, Z.A.B. 2013. Synthesis and characterisation of calcium carbonate aragonite nanocrystals from cockle shell powder (Anadara granosa). Journal of Nanomaterials 2013: 398357.

Shafiu, K.A. \& Zakaria, Z.A.B. 2014. Osteoblasts growth behaviour on biobased calcium carbonate aragonite nanocrystal. BioMed Research International 2014: 215097. 
Sharma, C., Dinda, A.K., Potdar, P.D., Chou, C.F. \& Mishra, N.C. 2016. Fabrication and characterization of novel nanobiocomposite scaffold of chitosan-gelatin-alginatehydroxyapatite for bone tissue engineering. Materials Science and Engineering $C$ 64: 416-427.

Szabo, K. 2008. Shell as a raw material: Mechanical properties and working techniques in the tropical Indo-West Pacific. Archaeofauna 17: 125-138.

Taylor, J.D., Kennedy, W.J. \& Hall, A. 1969. The shell structure and mineralogy of the Bivalvia. Introduction. Nuculacea Trigonacea. Bulletin of the British Museum (Natural History) Zoology 3(Suppl.): 3-125.

Vinther, J., Sperling, E.A., Briggs, D.E.G. \& Peterson, K.J. 2012. A molecular palaeobiological hypothesis for the origin of aplacophoran molluscs and their derivation from chiton-like ancestors. Proceedings of the Royal Society $B$ 279: $1259-1268$

Williams, S.T. 2016. Molluscan shell colour. Biological Reviews 92(2): 1039-1058.

Xie, M., Olderøy, M., Andreassen, J.P., Selbach, S.M., Strand, B.L. \& Sikorski, P. 2010. Alginate-controlled formation of nanoscale calcium carbonate and hydroxyapatite mineral phase within hydrogel networks. Acta Biomater 6: 36653675.

Yin, J.,Zhang, S.,Zhang, H.W. \& Chen, B.S.2016. Band structure characteristics of nacreous composite materials with various defects. Zeitschrift fur Naturforschung-Section A Journal of Physical Sciences 71: 493-499.

Yin, J., Huang, J., Zhang, S., Zhang, H.W. \& Chen, B.S. 2014 Ultrawide low frequency band gap of phononic crystal in nacreous composite material. Physics Letters, Section A: General, Atomic and Solid State Physics 378: 2436-2442.

Yurimoto, T. 2014. Development of Blood Cockle Aquaculture Management Techniques in Malaysia. Fisheries Division, JIRCAS.

Zhang, J.,Liu, W., Schnitzler, V., Tancret, F. \& Bouler, J.M. 2014. Calcium phosphate cements for bone substitution: Chemistry, handling and mechanical properties. Acta Biomaterialia 10: 1035-1049.
Penny George, Zariyantey Abdul Hamid \& Hemabarathy

Bharatham*

Biomedical Science Programme

School of Health and Applied Sciences

Faculty of Health Sciences

Universiti Kebangsaan Malaysia

Jalan Raja Muda Abdul Aziz

50300 Kuala Lumpur, Federal Territory

Malaysia

Md Zuki Abu Bakar@Zakaria

Department of Veterinary Preclinical Sciences

Faculty of Veterinary Medicine

Universiti Putra Malaysia

43400 Serdang, Selangor Darul Ehsan

Malaysia

Enoch Kumar Perimal

Department of Biomedical Science

Faculty of Medicine and Health Sciences

Universiti Putra Malaysia

43400 Serdang, Selangor Darul Ehsan

Malaysia

*Corresponding author; email: hema@ukm.edu.my

Received: 9 September 2018

Accepted: 11 April 2019 